\title{
EFFECT OF SPRAYING BY NITROGEN LOADED ON CHITOSAN NANOPARTICLES ON GROWTH AND PRODUCTIVITY OF GARLIC UNDER SANDY SOIL CONDITIONS
}

\author{
Mohamed A. El-Sagan ${ }^{*}$, Mohamed S. Khater ${ }^{2}$ and Gebril A. El \\ Desouky ${ }^{1}$ \\ ${ }^{1}$ Department of Plant Production, Desert Research Center, El- \\ Matareya, Cairo, Egypt \\ ${ }^{2}$ National Institute of Laser Enhanced Science (NILES), Cairo \\ University, Egypt \\ *E-mail: drm_elsagan@yahoo.com
}

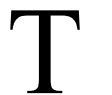

he field work was carried out at Baloza Research Station of the Desert Research Center, North Sinai Governorate, during the two consecutive winter seasons of 2015/2016 and 2016/2017. The experiments were conducted to study the effect of $\mathrm{N}$ fertilizer levels as soil addition $(0,50,75,100 \mathrm{~kg} / \mathrm{N} / \mathrm{fed})$; chitosan nanoparticles and $\mathrm{N}$ loaded on chitosan nanoparticles treatments as foliar application [Ch, $0.25(\mathrm{ChN} 1)$ and $0.5(\mathrm{ChN} 2)$ $\mathrm{mol} / \mathrm{L}]$ on growth, yield, chemical composition and storage potential of garlic plants, Chinese cv. grown in sandy soil conditions. Results revealed that $\mathrm{N}$ addition at the rate of $100 \mathrm{~kg}(\mathrm{~N} /$ fed) followed by 75 $\mathrm{kg}(\mathrm{N} / \mathrm{fed})$, were superior significantly in growth, yield, chemical composition and storage potential parameters in both growing seasons, when compared with control treatment. $\mathrm{N}$ loaded on chitosan nanoparticles spray at the rate of $0.5 \mathrm{~mol} / 1$ followed by 0.25 $\mathrm{mol} / \mathrm{l}$ gave significant increase in all growth, yield, chemical composition and storage characters potential in both growing seasons, when compared to control treatments. At the harvest date, the highest values of investment ratio were obtained with $\mathrm{N}$ loaded on chitosan nanoparticles spray at the rate of $0.5 \mathrm{~mol} / \mathrm{l}$ and $\mathrm{N}$ level at the rate of $100 \mathrm{~kg} \mathrm{~N} / \mathrm{fed}$ in the first season, and with $\mathrm{N}$ level at the rate of $75 \mathrm{~kg} \mathrm{~N} / \mathrm{fed}$ in the second season. The same trend of results was obtained with the end of storage period in both seasons. Linear correlation and regression of garlic traits were carried out. It may be worth to mention that with each increase of one gram of plant weight, total yield (ton/fed) of garlic correspondingly increased by 0.069 and 0.074 ton in the first and second seasons, respectively, and with each increase of one of percent of dry matter of garlic bulb, 
percent loss in weight of garlic correspondingly decreased 1.477 and 1.246 in the first and second seasons, respectively.

Keywords: garlic, $\mathrm{N}$ fertilizer, chitosan nanoparticles, growth, yield, chemical composition, storage potential

Garlic is one of main economic vegetable crops in Egypt. It has been used for its flavor and medical value. The increment of yield and improving quality of garlic is usually depending on many factors, which affect on plant growth and production. $\mathrm{N}$ fertilizer is necessary as success for crop production, especially in poor soil such as North Sinai Governorate, where soil nutrients are insufficient to meet the crop requirements. Many researchers proved that there is a direct relationship between either yield or its components and $\mathrm{N}$ fertilizer (Nori et al., 2012).

Moreover, increasing $\mathrm{N}$ fertilizer increased number of leaves, leaf length and plant growth. Sardi and Timar (2005) showed that garlic has a high $\mathrm{N}$ requirement, particularly in the early stages of growth. The highest yield was obtained with the treatment of $300 \mathrm{~kg} \mathrm{~N} / \mathrm{ha}$.

Availability of $\mathrm{N}$ is important for growing plants. It is a main constituent of protein and nucleic acid molecules. It is also a part of chlorophyll molecules. It is well known that the use of fertilizer helps in production and is a quick method to obtain the best yields (Farooqui et al., 2009). Moreover, $\mathrm{N}$ application significantly improved bulb yield and yield components (Abreham and Getachew, 2015).

Also, in a study carried out by Gaviola and Lipinski (2008), they showed that red and white garlic cultivars yielded 10 and 12 tons/ha with application 160 and $180 \mathrm{~kg} \mathrm{~N} / \mathrm{ha}$, respectively. On the other hand, Saigusa (2000) pointed out that 40 to $70 \%$ of N, 80 to $90 \%$ of phosphorus, and 50 to $70 \%$ of potassium of the normal fertilizers are lost and not absorbed by plants, causing economic and resource losses and dangerously increasing environmental pollution. Recently, the usage of slow release fertilizers has become a new tendency to save fertilizer consumption and to reduce environmental pollution (Wu and Liu, 2008 and Corradini et al., 2010). Also, it was suggested that use of controlled release $\mathrm{N}$ fertilizer combined with a supplement of other nutrients would be a sustainable strategy for fertilizer management in garlic production (Bo et al., 2016).

Chitosan is derived from chitin, a polysaccharide found in exoskeleton of shellfish such as shrimp, lobster or crabs and cell wall of fungi (Wojdyla, 2001). Recently, some researchers reported that chitosan enhanced plant growth and development (Chibu and Shibayama, 2003; Gornik et al., 2008 and Said et al., 2012). They reported that application of chitosan to plants increased key enzymes activities of $\mathrm{N}$ metabolism (nitrate reductase, glutamine synthetase and protease) as well as, improving the transportation of $\mathrm{N}$ in the functional leaves, which in turn, enhance plant

Egyptian J. Desert Res., 68, No. 1, 135-155 (2018) 
growth. In addition, Mondal et al. (2012) reported that growth, biochemical parameters and yield of okra were increased with increasing concentration of chitosan application up to $125 \mathrm{ppm}$. Moreover, chitosan treatment improved storability of post-harvest fruits and vegetables, because it forms a semi permeable film that regulates gas exchange and reduce transpiration and respiration, hence water loss was reduced and fruit ripening was slowed down. This effect has been reported by numerous horticultural commodities such as tomatoes and strawberries (Jiang and Li, 2001; Kittur et al., 2001; Bautista-Baños et al., 2006).

The evaluation of nanotechnology and emergence of novel nanodevices and nanomaterials open up new trends in agriculture. There are a large variety of methods that can be used in the production of nanoparticles, using techniques from both physics and chemistry. Chitosan nanoparticles have been investigated as a carrier for drug delivery, meanwhile a few studies have been attempted to discover the potential of chitosan nanoparticles as controlled release for NPK fertilizers. This presents the idea of developing encapsulated fertilizers in which NPK fertilizers are loaded within nanoparticles (Teodorescu et al., 2009). Also, some studies already proved the significance of nanofertilizers and its beneficial effects included the increases of nutrients use efficiency and yield quality, besides reduce soil pollution (Naderi and Danesh-Sharaki, 2013).

Corradini et al. (2010) pointed that the existence of electrostatic interactions between chitosan nanoparticles and the elements $\mathrm{N}, \mathrm{P}$ and $\mathrm{K}$. The stability of the CS-PMAA colloidal suspension was higher with the addition of $\mathrm{N}$ and potassium than with phosphorus, thus due to the higher anion charge from calcium phosphate than the anion charges from potassium chloride and urea. Moreover, Benzon et al. (2015) showed that nanofertilizer application promoted growth, development, and antioxidant activity in rice, demonstrating the potential to improve crop production and plant nutrition. In other words, nanofertilizers simply dissolve in solution and release the nutrient(s) as soluble ions. But, the dissolution rate and extent of nanofertilizers in water/soil solution should be higher than those of the related bulk (Liu and Lal, 2015).

The main objective of this work was to study the effect of $\mathrm{N}$ fertilizer levels as conventional fertilizer percent and chitosan nanoparticles, $\mathrm{N}$ loaded on chitosan nanoparticles on growth, yield, chemical composition and storage potential of garlic under North Sinai conditions.

\section{MATERIALS AND METHODS}

The field work was carried out at Baloza Research Station of the Desert Research Center, North Sinai Governorate, during the two consecutive winter seasons of 2015/2016 and 2016/2017.

The physical and chemical soil characteristics of the studied site were determined according to Page et al. (1982) and Klute (1986), 
respectively, as recorded in table (1). The chemical analysis of irrigation water was carried out using the standard method of Page et al. (1982) and presented in table (2).

Table (1). Some physical and chemical properties of the experimental soil site.

\begin{tabular}{|c|c|c|c|c|c|c|c|c|c|c|}
\hline \multirow{2}{*}{$\begin{array}{c}\text { Soil } \\
\text { depth } \\
\text { (cm) }\end{array}$} & \multirow[t]{2}{*}{$\begin{array}{l}\text { Texture } \\
\text { class }\end{array}$} & \multicolumn{3}{|c|}{$\begin{array}{c}\text { Soluble anions } \\
\text { (me/l) }\end{array}$} & \multirow{2}{*}{$\begin{array}{c}\text { pH } \\
\text { (Soil } \\
\text { paste) }\end{array}$} & \multirow[t]{2}{*}{$\begin{array}{c}\text { E.C } \\
\left(\mathrm{dSm}^{-1}\right)\end{array}$} & \multicolumn{4}{|c|}{ Soluble cations (me/l) } \\
\hline & & $\mathrm{HCO}_{3}^{-}$ & $\mathrm{SO}_{4}=$ & $\mathrm{Cl}^{-}$ & & & $\mathrm{Ca}^{+2}$ & $\mathbf{M g}^{+2}$ & $\mathrm{Na}^{+}$ & $\mathbf{K}^{+}$ \\
\hline $0-30$ & $\begin{array}{l}\text { Sandy } \\
\text { loam }\end{array}$ & 0.75 & 0.85 & 4.25 & 6.7 & 0.58 & 1.15 & 0.45 & 3.92 & 0.33 \\
\hline
\end{tabular}

Table (2). Chemical analysis of the irrigation water.

\begin{tabular}{|c|c|c|c|c|c|c|c|c|c|}
\hline \multirow{2}{*}{ Samples } & \multirow{2}{*}{ pH } & \multirow{2}{*}{$\begin{array}{c}\text { E.C. } \\
\left(\mathrm{dSm}^{-1}\right)\end{array}$} & \multicolumn{4}{|c|}{$\begin{array}{c}\text { Soluble cations } \\
(\mathrm{me} / \mathrm{l})\end{array}$} & \multicolumn{3}{|c|}{ Soluble anions $(\mathrm{me} / \mathrm{l})$} \\
\hline & & & $\mathrm{Ca}^{+2}$ & $\mathbf{M g}^{+2}$ & $\mathbf{N a}^{+}$ & $\mathbf{K}^{+}$ & $\mathrm{HCO}_{3}^{-}$ & $\mathrm{SO}_{4}{ }^{-2}$ & $\mathrm{Cl}^{-}$ \\
\hline $1^{\text {st }}$ season & 7.1 & 5.54 & 10.1 & 13.32 & 39.4 & 1.17 & 9.35 & 15.1 & 39.5 \\
\hline
\end{tabular}

\section{Chitosan Nanoparticles}

Chitosan (CTS, degree of deacetylation was 0.9 , average molecular weight was 6.0, 105, 99.9\%); acrylic acid (AA distilled under reduced pressure before use); acrylamide (AM), ammonium persulfate (APS, recrystallized from distilled water before use), urea $\mathrm{CO}\left(\mathrm{NH}_{2}\right)_{2}$ and $\mathrm{N}, \mathrm{N} 0$ methylenebisacrylamide (NNMBA, used as received). All materials were obtained from Sigma Aldrich Egypt.

\section{Preparation of Chitosan-coated $\mathbf{N}$}

$\mathrm{N}$ fertilizer granules from urea were placed into a rotary drum, and the CTS powder was stuck on the granules by epoxy dissolved in acetone. The adhesive was applied by spraying at regular time intervals. The process was finished until compact and homogeneous coating formed on fertilizer granules. The coated granules were dried at room temperature to a constant mass for $8 \mathrm{~h}$. The CTS-coated $\mathrm{N}$ fertilizer granules $(5 \mathrm{~g})$ were added into a flask with a mechanical stirrer, a condensed and separated by drop funnel. A certain amount of polyethylene glycoloctyl phenylether (OP), sorbite anhydride monostearic acid ester and carbon tetrachloride were added into the flask. The temperature was raised to $65^{\circ} \mathrm{C}$ using a water bath, while the contents were constantly stirred. After that, the mixed of partially neutralized acrylic acid (AA, by ammonia), acrylamide, N, N0-methylenebisacrylamide (NNMBA) solution, also, ammonium persulfate (APS) solution was slowly

Egyptian J. Desert Res., 68, No. 1, 135-155 (2018) 
dropped into the flask. The mixture was filtered to remove the carbon tetrachloride after being stirred for $2 \mathrm{~h}$ at $65^{\circ} \mathrm{C}$ and then dried at $70^{\circ} \mathrm{C}$ in oven to obtain the final product.

The incorporation of $\mathrm{N}$ fertilizers with chitosan nanoparticles was carried out by dissolving chitosan nanoparticles in different amounts of $\mathrm{N}$ fertilizers, each into $50 \mathrm{ml}$ of nanoparticle solution with magnetic stirring for $6 \mathrm{~h}$ at $25^{\circ} \mathrm{C}$. The chitosan concentration used in synthesis was $0.2 \%(\mathrm{w} / \mathrm{v})$. The incorporated $\mathrm{N}$ fertilizers into the chitosan nanoparticles resulted in the final concentrations of $0.25,0.5 \mathrm{~mol} \mathrm{~N}$ fertilizer as ammonium sulphate $(20.5 \% \mathrm{~N})$, and were calculated for requiring quantities according to the study treatments. The quantities were divided and applied four times after $30,60,90$ and 120 days from planting date.

Organic manure was added at the rate of $20 \mathrm{~m}^{3} / \mathrm{fed}$, while calcium super-phosphate $\left(15.5 \% \mathrm{P}_{2} \mathrm{O}_{5}\right)$ at the rate of $300 \mathrm{~kg} / \mathrm{fed}$. They were added during land preparation. Potassium sulphate $\left(48 \% \mathrm{~K}_{2} \mathrm{O}\right)$ was added at the rate of $150 \mathrm{~kg} / \mathrm{fed}$, the quantities were divided and applied two times after 60 and 90 days from planting date.

Garlic cloves were planted in the first week of October through the two growing seasons, respectively. Sixteen treatments were used, which were the combination of four $\mathrm{N}$ fertilizer levels as soil addition, i.e., 0,50 , $75,100 \mathrm{~kg} / \mathrm{N} /$ fed added as ammonium sulphate and four foliar treatments by chitosan nanoparticles. $\mathrm{N}$ was loaded on chitosan nanoparticles either with concentration of 0.25 or $0.5 \mathrm{~mol} / \mathrm{L}$ and control treatment sprayed with tap water.

Experimental plot area was 1/400 fed, [3 m (L0) x $3.5 \mathrm{~m}(\mathrm{~W})]$, which consisted of five ridges. Garlic cloves were soaked in warm water 12 $\mathrm{h}$ before planting, then planted within six lines for each ridge; $10 \mathrm{~cm}$ apart between cloves. Two ridges were dedicated for the vegetative growth samples and three ridges for the yield determination.

After 30, 60, 90 and 120 days from planting, chitosan nanoparticles were separated $(\mathrm{Ch})$ at the rate of $0.2 \%(\mathrm{w} / \mathrm{v})$, and $\mathrm{N}$ loaded on chitosan nanoparticles treatments were sprayed at concentrations of $0.25(\mathrm{ChN} 1)$ and $0.5(\mathrm{ChN} 2) \mathrm{mol} / \mathrm{L}$ on plants, while water was sprayed as a control treatment. All sprayed treatments were applied by hand dropping sprayer. The growing season extended for 180 days.

\section{Growth Parameters of Vegetative Growth}

After 150 days from planting, nine plants of each replicate were randomly taken for recording vegetative growth characteristics, i.e., plant height and weight, number of leaves/plant and percentage of dry weight of the aerial vegetative parts.

\section{Yield and Its Components}

Egyptian J. Desert Res., 68, No. 1, 135-155 (2018) 
At harvesting stage (180 days from planting date) a sample of 20 garlic plants were randomly taken from each experimental plot for yield characteristics, i.e., neck and bulb diameter, average bulb fresh weight, percentage dry matter of bulb were recorded. In addition, total yield (ton/fed), when $50 \%$ of leaves pended and turned to yellowish green color. Irrigation was stopped at 15 days before harvest date, plants of each experiment plot were collected and put in shadow and aired place for 10 to 15 days for drying care. After that, every 30 plants were tied together for storage.

\section{Chemical Composition}

Three samples of garlic bulb from each subplot were taken and oven dried at $70^{\circ} \mathrm{C}$ until stable weight, then ground to fine particles and used to determine chemical content, such as minerals and calcium percentage were measured using flame photometer method as described by Brown and Lilliland (1964). Total $\mathrm{N}$ was determined using the modified micro Kjeldah method (Cottenie et al., 1982), while total soluble solids (TSS) of garlic cloves were determined using a JK-SR-113ATC digital Refractometer (Shanghi Co. Ld., China) at $20^{\circ} \mathrm{C}$ (A.O.A.C., 1975).

\section{Storage Potential}

Uniform samples of garlic plants from each experimental were selected, cleaned, weighted and stored in net bags at room temperature with aeration conditions under shadow for 6 months. Average room temperature was between 23.5 and $25.6^{\circ} \mathrm{C}$ and air humidity were 80 and $85 \%$. Examination was carried out to calculate the percentage of loss in weight and decay.

\section{Investment Ratio}

Investment Ratio $(\mathrm{IR})=($ total revenue, $\mathrm{LE} /$ total cost, $\mathrm{LE})$ following Rana et al. (1996).

\section{Experimental Design and Statistical Analysis}

The experimental treatments were arranged in split plot design with four replicates, the main plots were assigned for $\mathrm{N}$ levels, whereas, spray treatments rates were randomly arranged in the sub plots. Statistical analyses of obtained data were analyzed according to Thomas and Hills (1975).

\section{RESULTS AND DISCUSSION}

\section{Plant Growth Parameters}

Growth parameters results, i.e., plant height and weight, no. of leaves/plant and leaves dry matter percent are presented in tables (3 and 4) and indicate that there were significant positive effects for both $\mathrm{N}$ levels and 
foliar application on all investigated growth parameters. From the data, it could remark the following:

- Growth parameter values were superior significantly with $\mathrm{N}$ at rate of 100 $\mathrm{kg}(\mathrm{N} / \mathrm{fed})$, followed by $75 \mathrm{~kg}(\mathrm{~N} / \mathrm{fed})$, when compared with control treatment (without $\mathrm{N}$ application). Also, that there were no significant difference between 75 and $100 \mathrm{~kg} \mathrm{~N} /$ fed treatments in all growth parameters measurements in both growing seasons, except the highest value of dry matter percentage of leaves recorded with $100 \mathrm{~kg} \mathrm{~N} / \mathrm{fed}$ in the first season only. These results agree with those reported in the study of determination of the optimal source and level of fertilizer by Nori et al. (2012). They found that $\mathrm{N}$ had a positive effect on morphological characteristics of garlic. The results showed that the highest leaf length and leaves number were observed with $300 \mathrm{~kg} \mathrm{~N} / \mathrm{ha}$ application. Also, increasing $\mathrm{N}$ fertilizer enhanced the growth trend of leaves number, length beside plant weight (Sardi and Timar, 2005)

- The highest values of growth parameters were reported with foliar spray by $\mathrm{N}$ loaded on chitosan nanoparticles at the rate of 0.5 and $0.25 \mathrm{~mol}$, respectively in both growing seasons, when compared to control treatment.

(foliar spray by tap water). Moreover, no significant difference has been found between foliar spray by chitosan nanoparticles only and $\mathrm{N}$ loaded on chitosan nanoparticles at the rate of $0.25 \mathrm{~mol}$ in plant weight and percent dry matter of leaves in both growing seasons. The results were in the same line with those reported by Chibu and Shibayama (2003), Gornik et al. (2008) and Said et al. (2012). They showed that chitosan enhanced plant growth and development. Application of chitosan increased key enzymes activities of $\mathrm{N}$ metabolism and improved the transportation of $\mathrm{N}$ in the functional leaves, which is in turn, enhanced plant growth. The results also, agreed with those obtained by Benzon et al. (2015). They showed that nanofertilizer application promoted the growth, development, and antioxidant activity. Also, the interaction between two factors showed no significant in all growth parameters in both seasons.

\section{Yield and Its Components}

Tables (4 and 5) presented data of neck and bulb diameter, bulb weight, percent bulb dry matter and total yield/ton per fed. The results indicated that yield and its components were affected by the two investigated factors, i.e., $\mathrm{N}$ levels and foliar application. The results could remark the following:

- It is clear from the data that neck and head diameter, head weight, percent head dry matter and total yield significantly increased with $\mathrm{N}$ addition at rate of $100 \mathrm{~kg}(\mathrm{~N} / \mathrm{fed})$, followed by $75 \mathrm{~kg}(\mathrm{~N} / \mathrm{fed})$, when compared with control treatment (without $\mathrm{N}$ application). No significant differences 
observed among treatments in yield and its components, except the height value of neck diameter recorded with $\mathrm{N}$ at the rate of $100 \mathrm{~kg} \mathrm{~N} / \mathrm{fed}$ in both growing seasons. It is well known that the use of fertilizer improved production (Farooqui et al., 2009). Moreover, the highest yield was obtained with the treatment of $300 \mathrm{~kg} \mathrm{~N} / \mathrm{ha}$ (Sardi and Timar, 2005). N application significantly influenced bulb yield and yield component (Abreham and Getachew, 2015).

- The highest values of neck and head diameter, head weight, head dry matter (\%) and total yield were recorded with foliar spray as compared with control treatment (spray by tap water) in both growing seasons. The same trend was observed with Benzon et al. (2015), that there were no significant differences between $\mathrm{N}$ loaded on chitosan nanoparticals application at the rates of 0.5 and $0.25 \mathrm{~mol}$, regarding neck and head diameter, head weight, head dry matter (\%) and total yield in both growing seasons, except the highest values of head diameter and percent head dry matter, which were superior significantly with $\mathrm{N}$ loaded on chitosan nanoparticals application at the rates of $0.5 \mathrm{~mol}$ in the second season only. Nanofertilizer application promoted the growth, development and antioxidant activity, also demonstrating the potential to improve crop production and plant nutrition.

- The interaction between the two factors showed that the highest values of head weight were recorded with $\mathrm{N}$ level at the rate of $100 \mathrm{~kg} \mathrm{~N} / \mathrm{fed}$ combined with $\mathrm{N}$ loaded on chitosan nanoparticles at the rate of 0.5 and $0.25 \mathrm{~mol}$, respectively in the first season only.

\section{Chemical Content}

Obtained results in table (6) indicated significant positive effect for both studied factors, i.e., $\mathrm{N}$ levels and $\mathrm{N}$ loaded on chitosan nanoparticles application on chemical components.

- The highest values of $\mathrm{N}(\%)$ were recorded with $\mathrm{N}$ application at the rate of $100 \mathrm{~kg} \mathrm{~N} / \mathrm{fed}$, and the highest values of T.S.S. were observed with $\mathrm{N}$ application at the rate of 75 and $50 \mathrm{~kg} \mathrm{~N} /$ fed in both growing seasons. Also, no significant differences among all $\mathrm{N}$ levels observed on $\mathrm{Ca}(\%)$ content in both seasons. Availability of $\mathrm{N}$ is important for growing plants. It is a main constituent of protein and nucleic acid molecules. It is also a part of chlorophyll molecules (Farooqui et al., 2009).

- The highest values of N, Ca (\%) and T.S.S. were recorded with $\mathrm{N}$ loaded on chitosan nanoparticles spray at the rate of $0.5 \mathrm{~mol}$. No significant differences were observed when compared with $\mathrm{N}$ loaded on chitosan nanoparticles spray at the rate of $0.25 \mathrm{~mol}$ in both seasons. On the other

Egyptian J. Desert Res., 68, No. 1, 135-155 (2018) 


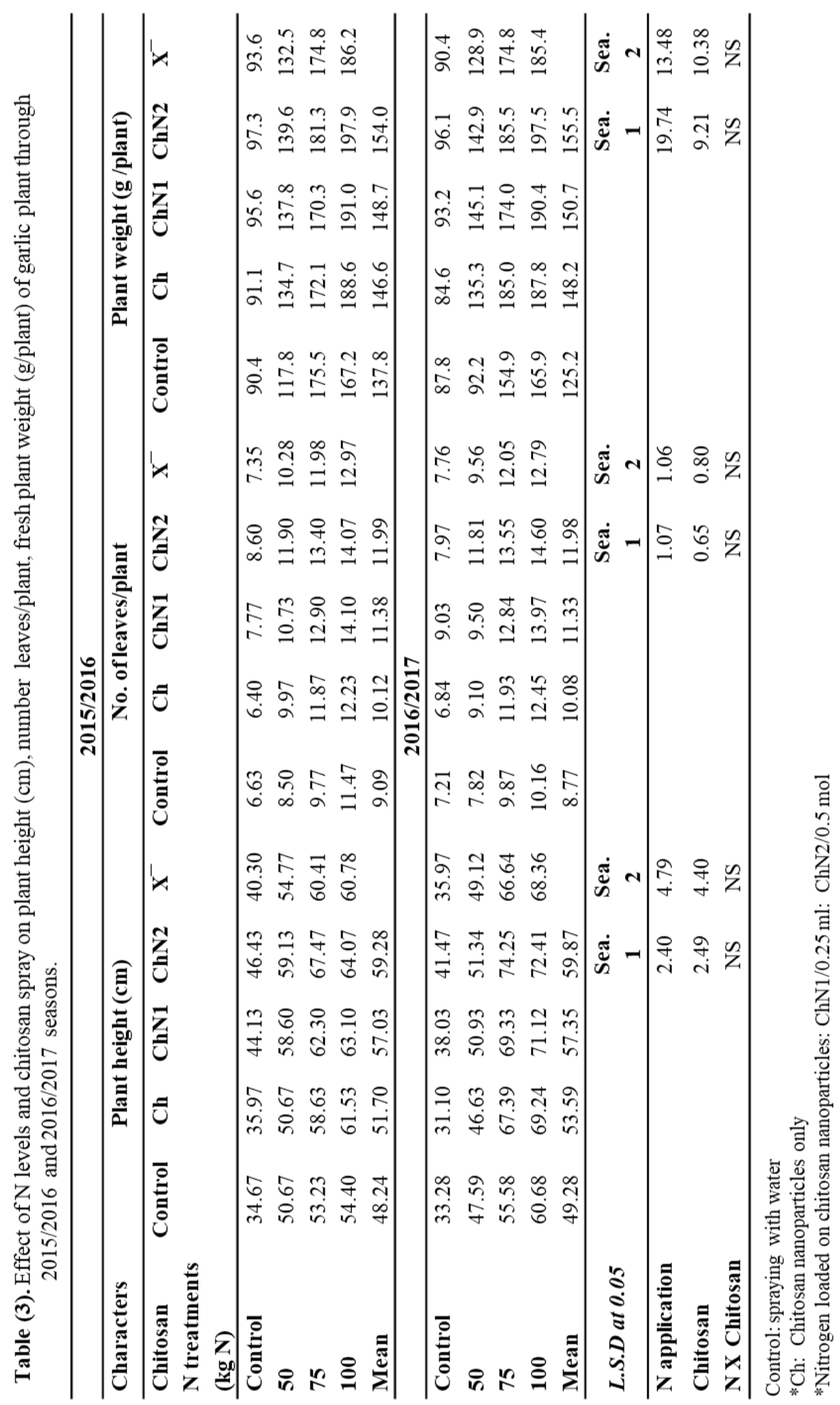

Egyptian J. Desert Res., 68, No. 1, 135-155 (2018) 


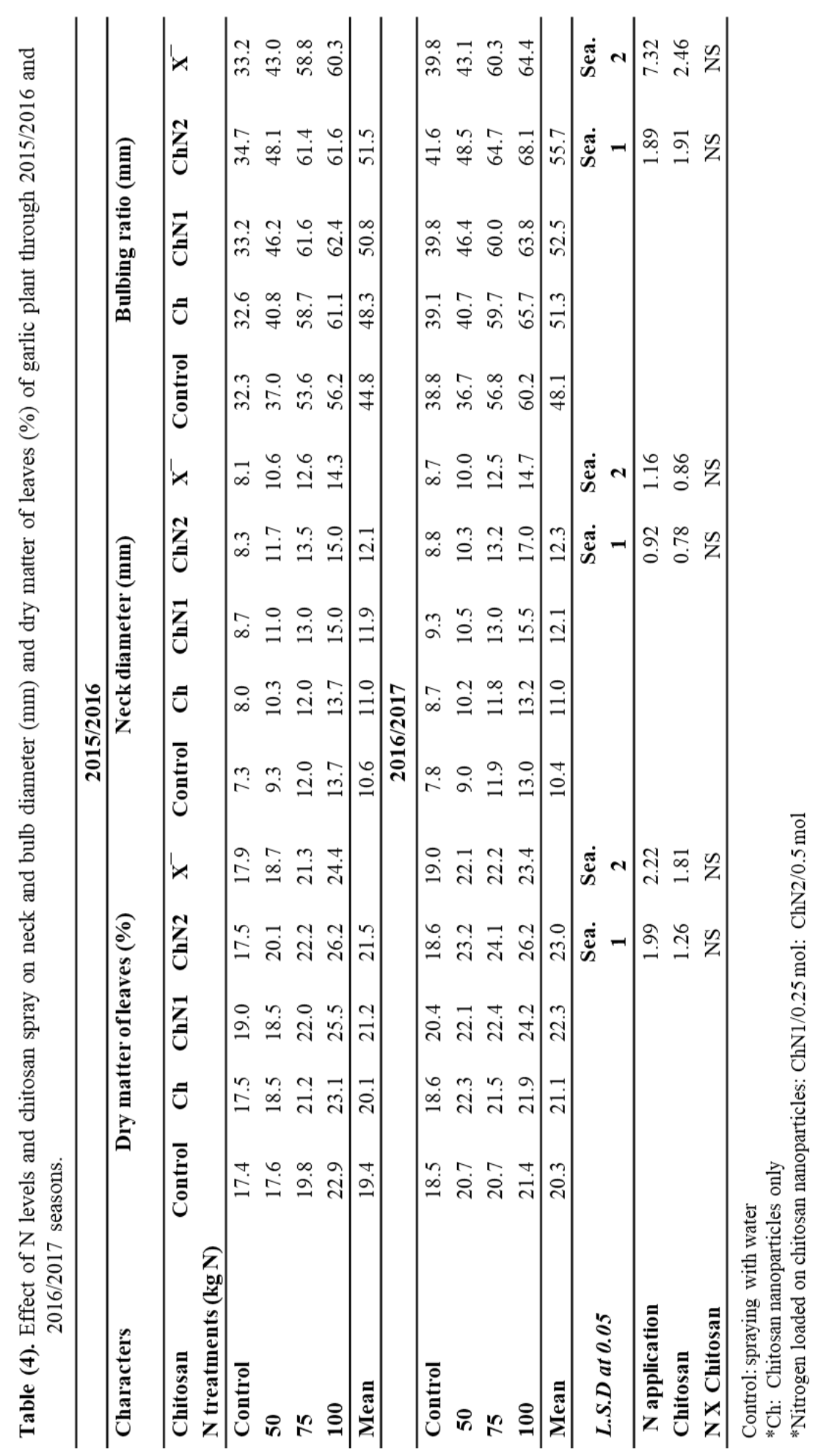

Egyptian J. Desert Res., 68, No. 1, 135-155 (2018) 


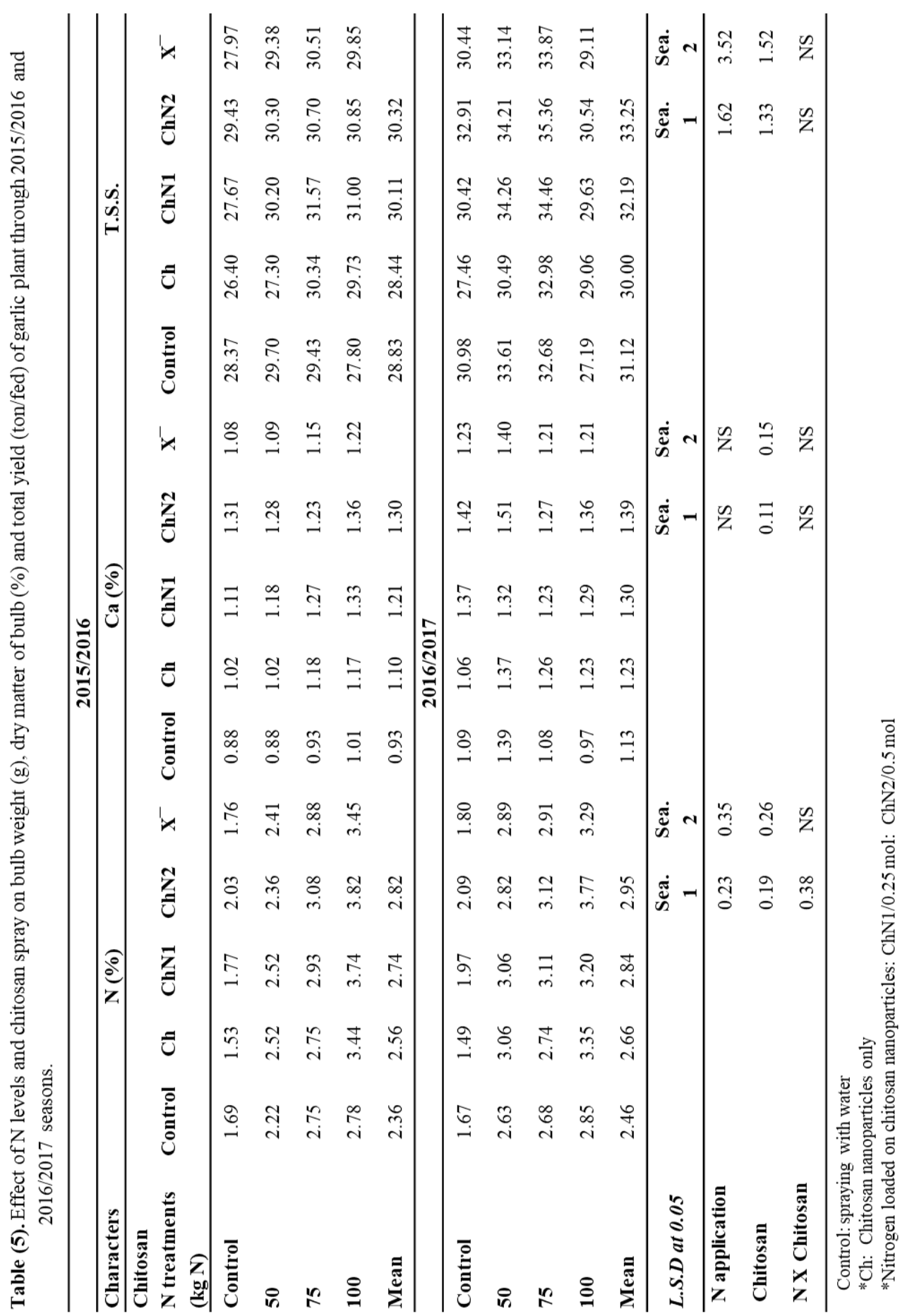

Egyptian J. Desert Res., 68, No. 1, 135-155 (2018) 


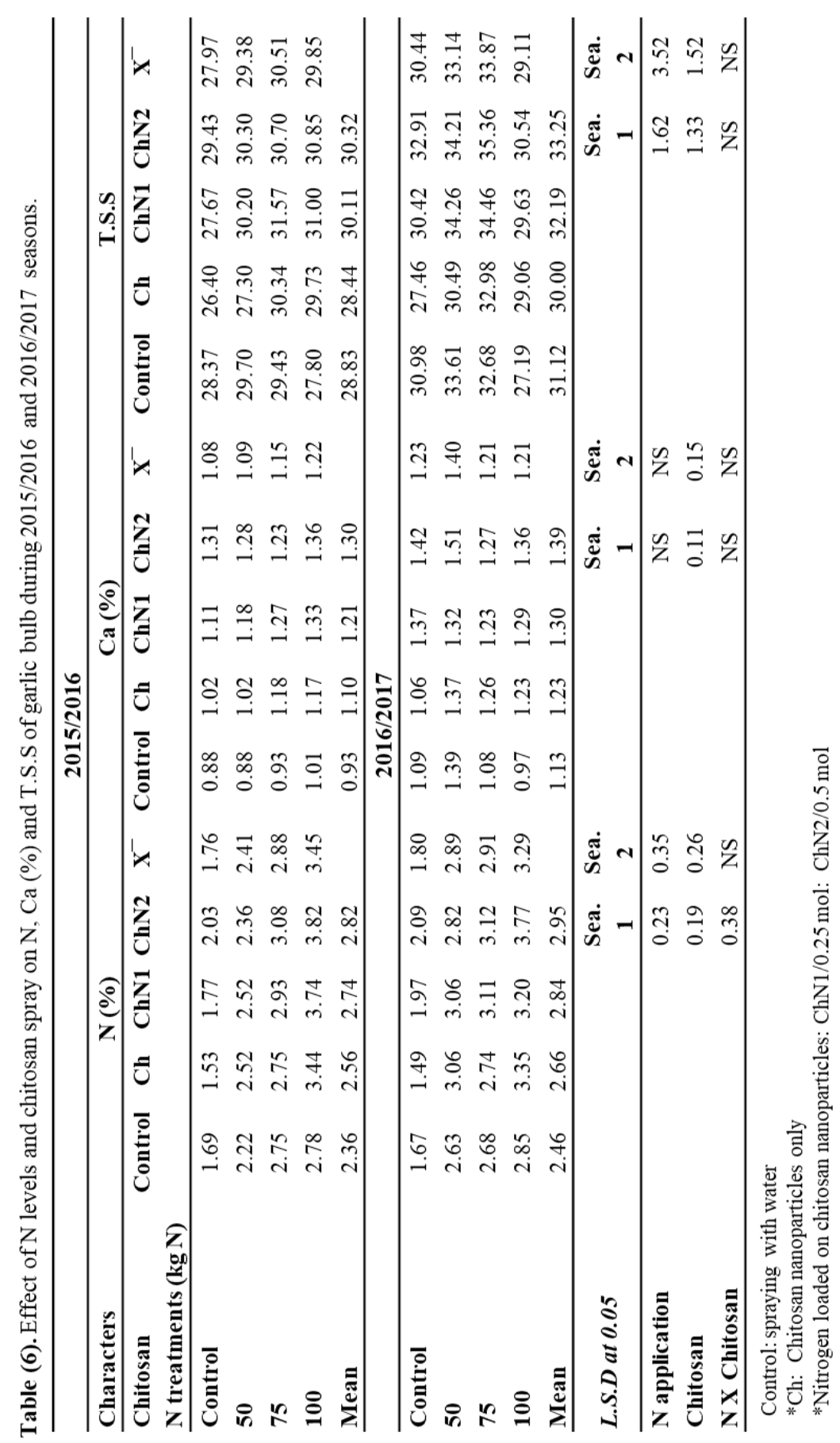

Egyptian J. Desert Res., 68, No. 1, 135-155 (2018) 
hand, there were no significant differences between treatments of $\mathrm{N}$ loaded on chitosan nanoparticles and chitosan nanoparticles only regarding $\mathrm{N}$ and $\mathrm{Ca} \%$ in both seasons.

- Some studies already proved the positive significance of nanofertilizers. Some beneficial effects include increases in nutrient use efficiency (Naderi and Danesh-Sharaki, 2013). Also, nanofertilizers simply dissolve in solution and release the nutrient(s) as soluble ions (Liu and Lal, 2015).

- The interaction between the two factors showed that the heights value of $\mathrm{N}(\%)$ were recorded with $\mathrm{N}$ level at the rate of $100 \mathrm{~kg} \mathrm{~N} /$ fed combined with $\mathrm{N}$ loaded on chitosan nanoparticles at the rate of 0.5 , followed by $0.25 \mathrm{~mol}$, respectively in the first season only.

\section{Storage Potential}

Data presented in table (7) clear the percentage of loss in weight and decay of garlic. These parameters were affected with the two investigated factors, i.e., $\mathrm{N}$ levels and chitosan nanoparticles application. Obtained data could remark the following:

- The lowest values of loss in weight percent were recorded with $\mathrm{N}$ level at the rate of $(75 \mathrm{~kg} \mathrm{~N} / \mathrm{fed})$ when compared with control treatment. No significant differences recorded among $\mathrm{N}$ levels at the rate of 50, 75 and $100 \mathrm{~kg} \mathrm{~N} / \mathrm{fed}$, in both seasons. On the other hand, the highest value of decay (\%) was recorded with control treatment but no significant differences found between $\mathrm{N}$ level at the rate of 75 and $100 \mathrm{~kg} \mathrm{~N} / \mathrm{fed}$, in both seasons.

- The lowest values of loss in weight percent were recorded with $\mathrm{N}$ loaded on chitosan nanoparticles application at the rate of $0.5 \mathrm{~mol}$ when compared with control treatment. No significant differences among all chitosan nanoparticles application were observed in both seasons. On the other hand, the highest value of decay (\%) was recorded with control treatment. Chitosan treatments may improve storability of post-harvest vegetables, because it forms a semi permeable film that regulate the gas exchange and reduce transpiration, respiration and water loss, also fruit ripening is slowed down. These effects have been reported for numerous horticultural commodities; such as tomatoes, strawberries and bell pepper (Jiang and Li, 2001; Kittur et al., 2001; Bautista-Baños et al., 2006).

\section{Investment Ratio (IR)}

The final goal of any agricultural application is to get profitable yield as a gain from the investment as the highest possible rate of revenue. Table (8) shows the calculation of input for all treatments, while table (9) gives the investment ratio for all treatments

Egyptian J. Desert Res., 68, No. 1, 135-155 (2018) 
at the harvest date and after 6 months from storage. Data presented in table (8) show that the fixed cost for one fed of garlic under control (without $\mathrm{N}$ addition), 50, 75 and $100 \mathrm{~kg} \mathrm{~N} /$ fed were 10000, 10450, 10675 and $10900 \mathrm{LE}$ in the first season and 12550, 13250, 13600 and $13950 \mathrm{LE}$, respectively in the second season. While, price of one $\mathrm{kg}$ of garlic at harvest date and after six months from storage were 2 and $9 \mathrm{LE}$ in the first season and 3.5 and $13 \mathrm{LE}$ in the second season, respectively.

Table (7). Effect of [N] levels and chitosan spray on percent loss in weight and percent decay and disease after six month of storage periods during 2015/2016 and 2016/2017 seasons.

\begin{tabular}{|c|c|c|c|c|c|c|c|c|c|c|}
\hline \multicolumn{11}{|c|}{$2015 / 2016$} \\
\hline Characters & \multicolumn{5}{|c|}{ Percent loss in weight } & \multicolumn{5}{|c|}{ Percent decay } \\
\hline $\begin{array}{l}\text { Chitosan [N] } \\
\text { Treatments (kg N) }\end{array}$ & Cont. & Ch & ChN1 & ChN2 & $\mathbf{X}^{-}$ & Cont. & Ch & ChN1 & ChN2 & $\mathbf{X}^{-}$ \\
\hline Control & 56.10 & 52.40 & 51.10 & 48.57 & 52.04 & 36.27 & 28.93 & 27.77 & 29.00 & 30.49 \\
\hline 50 & 54.13 & 47.77 & 47.60 & 44.33 & 48.46 & 29.00 & 26.00 & 24.33 & 25.00 & 26.08 \\
\hline 75 & 52.90 & 43.63 & 42.47 & 42.50 & 45.38 & 25.67 & 25.00 & 22.33 & 20.87 & 23.47 \\
\hline 100 & 55.53 & 43.70 & 42.83 & 44.17 & 46.56 & 24.00 & 21.67 & 21.10 & 20.57 & 21.83 \\
\hline Mean & 54.67 & 46.88 & 46.00 & 44.89 & & 28.73 & 25.40 & 23.88 & 23.86 & \\
\hline \multicolumn{11}{|c|}{ 2016/2017 } \\
\hline Control & 58.63 & 51.33 & 45.14 & 48.23 & 50.83 & 39.27 & 33.01 & 29.52 & 32.47 & 33.57 \\
\hline 50 & 54.37 & 44.15 & 47.35 & 41.37 & 46.81 & 31.64 & 29.78 & 27.59 & 29.55 & 29.64 \\
\hline 75 & 53.14 & 42.24 & 40.85 & 41.30 & 44.38 & 32.49 & 29.03 & 24.39 & 24.78 & 27.67 \\
\hline 100 & 52.80 & 41.73 & 42.69 & 42.15 & 44.84 & 27.55 & 27.05 & 27.09 & 25.20 & 26.72 \\
\hline Mean & 54.74 & 44.86 & 44.01 & 43.26 & & 32.74 & 29.72 & 27.15 & 28.00 & \\
\hline L.S.D at 0.05 & & & & Sea. 1 & Sea. 2 & & & & Sea. 1 & Sea. 2 \\
\hline $\mathrm{N}$ application & & & & 3.35 & 2.71 & & & & 1.35 & 2.71 \\
\hline Chitosan & & & & 2.52 & 2.79 & & & & 1.61 & 2.10 \\
\hline N X Chitosan & & & & NS & NS & & & & NS & NS \\
\hline
\end{tabular}

The increasing cost of input units and of price final products in the second season, was due to The Central Bank of Egypt decided Edit exchange of Egyptian pound against US dollar, it lead to higher prices in November 2016. Also, $\mathrm{N}$ loaded on chitosan nanoparticles treatments was not calculated in input costs, because it represents a little value. From data presented in table (9), the highest values of investment ratio were obtained with $\mathrm{N}$ level application at the rate of $100 \mathrm{~kg} \mathrm{~N} /$ fed and $\mathrm{N}$ loaded on chitosan nanoparticles spray at the rate

Egyptian J. Desert Res., 68, No. 1, 135-155 (2018) 
of $0.5 \mathrm{~mol}$ at harvest date in the first season. However, the highest values were obtained with $\mathrm{N}$ level at the rate of $75 \mathrm{~kg} \mathrm{~N} / \mathrm{fed}$ and $\mathrm{N}$ loaded on chitosan nanoparticles spray at the rate of $0.5 \mathrm{~mol}$ at the harvest date in the second season. The same trend of results was obtained after storage period in both seasons.

Table (8). Fixed and variable input and output for garlic production (LE/fed).

\begin{tabular}{|c|c|c|c|c|c|c|}
\hline \multirow{3}{*}{ Items } & \multicolumn{2}{|c|}{ Items } & \multicolumn{4}{|c|}{ Season } \\
\hline & \multirow{2}{*}{ Unit } & \multirow[t]{2}{*}{ Counts } & \multicolumn{2}{|c|}{ First season } & \multicolumn{2}{|c|}{ Second season } \\
\hline & & & $\begin{array}{l}\text { Unit } \\
\text { cost }\end{array}$ & $\begin{array}{c}\text { Total } \\
\text { LE }\end{array}$ & $\begin{array}{l}\text { Unit } \\
\text { cost }\end{array}$ & $\begin{array}{c}\text { Total } \\
\text { LE }\end{array}$ \\
\hline \multicolumn{7}{|l|}{ Fixed $\operatorname{cost} /$ fed } \\
\hline Land preparation & Hour & 4.0 & 50 & 200 & 75.0 & 300 \\
\hline Organic fertilizer & $\mathrm{m}^{3}$ & 20.0 & 100 & 2000 & 130.0 & 2600 \\
\hline Chemical fertilizer as & & & & 1200 & & 1450 \\
\hline \multicolumn{7}{|l|}{ Calcium super-phosphate } \\
\hline \multicolumn{7}{|l|}{ Potassium sulphate } \\
\hline Garlic seed & $\mathrm{kg}$ & 350.0 & 10 & 3500 & 12.0 & 4200 \\
\hline Labor cost & Worker/day & & & & & \\
\hline 1. Fertilizer add & & 5.0 & 60 & 300 & 80.0 & 400 \\
\hline 2. Planting cloves & & 10.0 & 60 & 600 & 80.0 & 800 \\
\hline 3. Seasonal labor & & 15.0 & 60 & 900 & 80.0 & 1200 \\
\hline 4. Harvest labor & & 5.0 & 60 & 300 & 80.0 & 400 \\
\hline Pesticides & Liter & 7.0 & 100 & 700 & 120.0 & 840 \\
\hline Foliar fertilizer & Liter & 3.0 & 100 & 300 & 120.0 & 360 \\
\hline Total & & & & 10000 & & 12550 \\
\hline \multicolumn{7}{|l|}{ Variable cost } \\
\hline Ammonium sulphate $(20.5 \% \mathrm{~N})$ & Packet & & & & & \\
\hline $100 \mathrm{~kg} \mathrm{~N} / \mathrm{fed}$ & & 10.0 & 90 & 900 & 140.0 & 1400 \\
\hline $75 \mathrm{~kg} \mathrm{~N} / \mathrm{fed}$ & & 7.5 & & 675 & & 1050 \\
\hline $50 \mathrm{~kg} \mathrm{~N} / \mathrm{fed}$ & & 5.0 & & 450 & & 700 \\
\hline Chitosan nanoparticles cost & Liter & 1.0 & 350 & 1 & 450.0 & \\
\hline Storage cost for 6 months & & & & 1000 & & 1500 \\
\hline \multicolumn{7}{|l|}{ Output (price of kg) } \\
\hline 1. Yield at harvest & $\mathrm{kg}$ & 1.0 & 2 & & 3.5 & \\
\hline 2. Yield after 6 months storage & $\mathrm{kg}$ & 1.0 & 9 & & 13.0 & \\
\hline
\end{tabular}

Egyptian J. Desert Res., 68, No. 1, 135-155 (2018) 
Table (9). Investment ratio (IR) for $\mathrm{N}$ levels and chitosan nanoparticles application treatments (LE input/ LE output) during 2015/2016 and 2016/2017 seasons.

\begin{tabular}{|c|c|c|c|c|c|c|c|c|}
\hline \multicolumn{9}{|c|}{$2015 / 2016$} \\
\hline Characters & \multicolumn{4}{|c|}{ Investment ratio at harvest date } & \multicolumn{4}{|c|}{ Investment ratio after storage } \\
\hline $\begin{array}{l}\text { Chitosan } \\
\text { N treatments }(\mathrm{kg} \mathrm{N})\end{array}$ & Control & $\mathbf{C h}$ & ChN1 & ChN2 & Control & Ch & ChN1 & ChN2 \\
\hline control & 0.63 & 0.61 & 0.70 & 0.75 & 1.13 & 1.20 & 1.40 & 1.57 \\
\hline 50 & 1.16 & 1.14 & 1.17 & 1.37 & 2.18 & 2.46 & 2.52 & 3.15 \\
\hline 75 & 1.40 & 1.66 & 1.87 & 1.91 & 2.72 & 3.87 & 4.44 & 4.53 \\
\hline 100 & 1.66 & 1.66 & 1.87 & 1.94 & 3.04 & 3.87 & 4.41 & 4.47 \\
\hline \multicolumn{9}{|c|}{$2016 / 2017$} \\
\hline control & 0.88 & 0.95 & 1.01 & 1.06 & 1.21 & 1.55 & 1.85 & 1.83 \\
\hline 50 & 1.45 & 1.51 & 1.59 & 1.85 & 2.21 & 2.82 & 2.81 & 3.64 \\
\hline 75 & 1.88 & 2.57 & 2.78 & 3.08 & 2.95 & 4.98 & 5.51 & 6.07 \\
\hline 100 & 2.35 & 2.38 & 2.76 & 2.91 & 3.72 & 4.67 & 5.32 & 5.67 \\
\hline
\end{tabular}

\section{Correlation and Regression of Some Garlic Traits}

It is being worth to mention that fresh plant weight ( $\mathrm{g}$ ) of garlic was significantly positively correlated with number of leaves/plant (Fig. 1). Corresponding correlation coefficients (r) were 0.915 and 0.924 in the first and second seasons, respectively. Corresponding coefficients of determination were 0.838 and 0.853 in the first and second seasons, respectively. It means that 83.3 to $85.3 \%$ of plant fresh weights were related to leaves number per plant. In addition, linear regression coefficients of plant weight on leaves number were 14.06 and 1.36 in the first and second seasons, respectively, which are indicated that for each increase of one leaf, fresh weight of plant correspondingly increased by 14.06 and $15.36 \mathrm{~g}$.

Similarly, highly significant positive correlation was assisted between total yield (ton/fed) and fresh weight of plant (g). Corresponding regressions coefficients were 0.069 and 0.074 in the first and second seasons, respectively. This indicated that for each increase of one gram of plant weight and total yield (ton/fed) of garlic correspondingly increased by 0.069 and 0.074 ton in the first and second seasons, respectively.

Moreover, fig. (2) indicates that dry matter of garlic bulb (\%) was significantly positively correlated with $\mathrm{N}$ content (\%) of bulb. Corresponding correlation coefficients (r) were 0.953 and 0.833 in the first and second seasons, respectively. This indicated that for each increase of one percent of $\mathrm{N}$ content, dry matter (\%) of garlic bulb correspondingly increased by 3.477

Egyptian J. Desert Res., 68, No. 1, 135-155 (2018) 
and 3.990 in the first and second seasons, respectively. Also, percentage of loss in weight of garlic was significantly negatively correlated with dry matter of bulb (\%). Corresponding regression coefficients were -1.477 and 1.246 in the first and second seasons, respectively, which indicated that for each increase of one percent of dry matter of garlic bulb, percentage of loss in weight of garlic correspondingly decreased 1.477 and 1.246 in the first and second seasons, respectively.

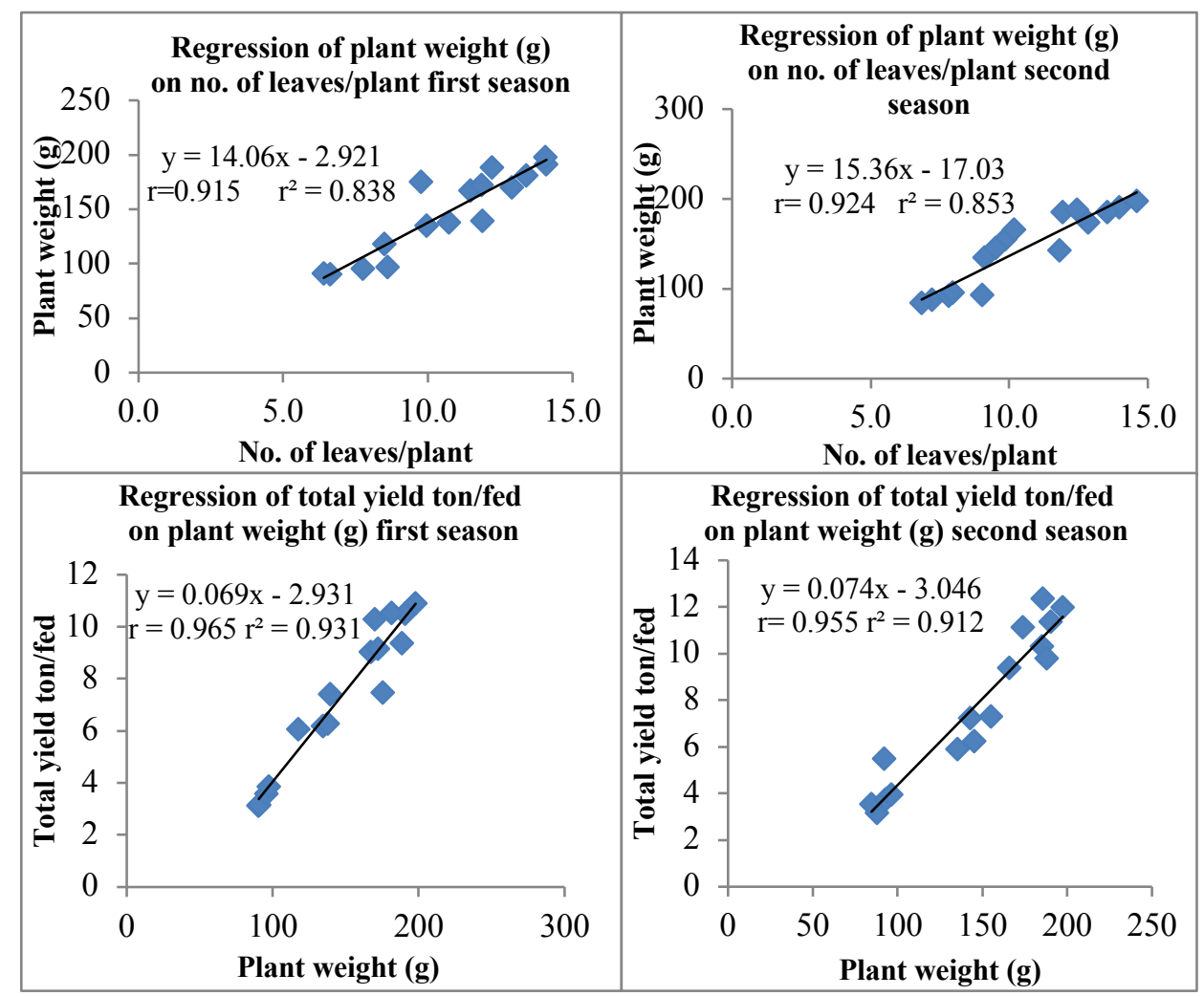

Fig. (1). Correlation coefficients (r), coefficients of determination $\left(\mathrm{r}^{2}\right)$ and regression coefficients of garlic yield on plant fresh weight and plant fresh weight on number of leaves/plant.

Egyptian J. Desert Res., 68, No. 1, 135-155 (2018) 


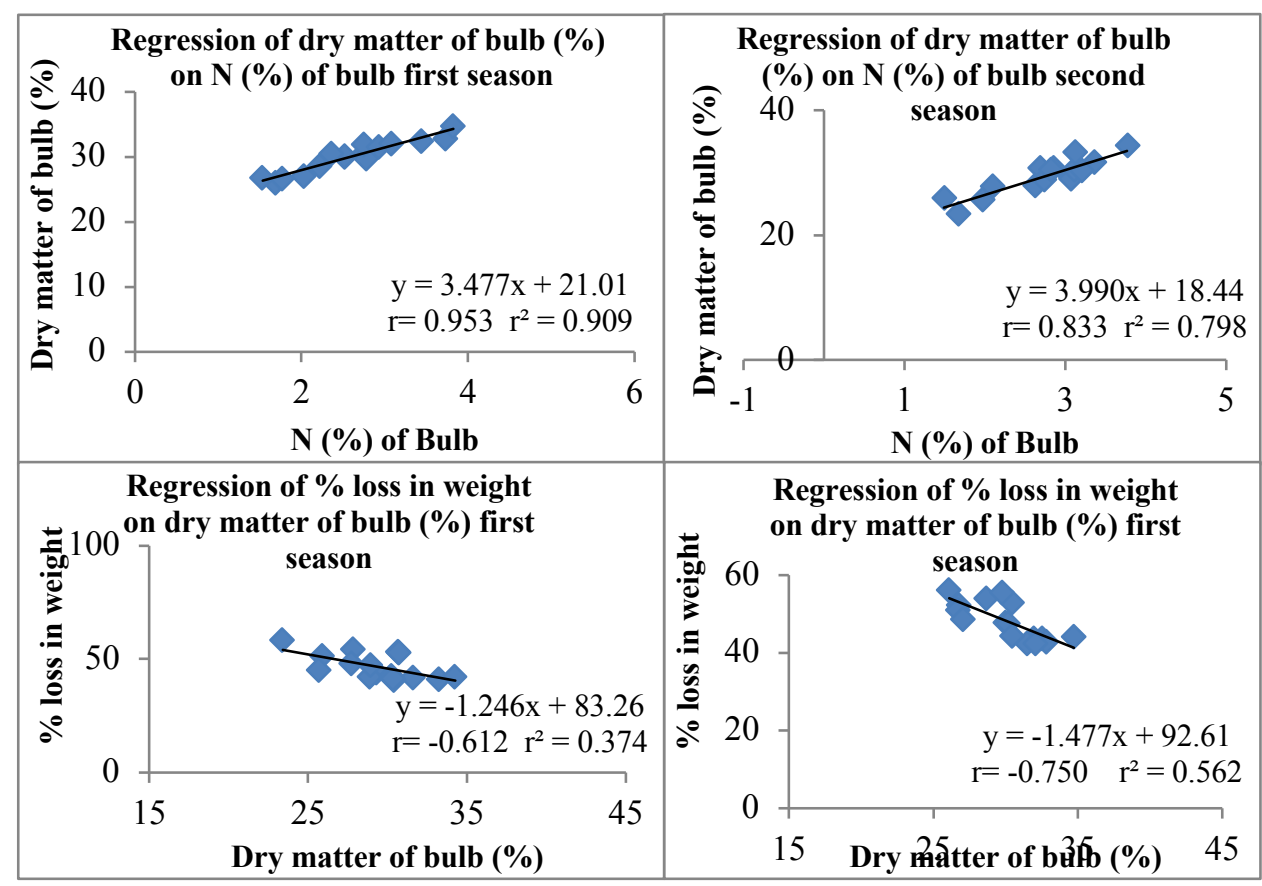

Fig. (2). Correlation coefficients (r), coefficients of determination $\left(\mathrm{r}^{2}\right)$ and regression coefficients of dry matter of bulb (\%) on $\mathrm{N}(\%)$ of bulb and head percentage loss in weight on dry matter of bulb (\%).

\section{REFERENCES}

A.O.A.C. (1975). In "Official Methods of Analysis of the Association of Official Ana Lytical Chemists". 12 ${ }^{\text {th }}$ Ed. Published by the Assocation of Official Analytical Chemists. Benjamin. Frank Line Station, Washington, DC.

Abreham, M. and E. Getachew (2015). The effects of [N] and phosphorus on yield and yield components of garlic (Allium sativum L.) varieties at Beressa watershed, Mesqan Woreda, South Central-Ethiopia. Glob. J. Agric. Agric. Sci., 3 (2): 197-202.

Bautista-Baños, S., A.N. Hernández-Lauzardo and M.G. Velázquez-del Valle (2006). Chitosan as a potential natural compound to control pre and postharvest diseases of horticultural commodities. Crop Prot., 25: 108-118.

Benzon H.R.L., M.R.U. Rubenecia, V.U. Ultra and J.S.C. Lee (2015). Nano-fertilizer affects the growth, development, and chemical properties of rice. Int. J. Agro. Agri. Res., 7 (10): 105-117.

Egyptian J. Desert Res., 68, No. 1, 135-155 (2018) 
Bo, Luji, Y. Zhang, Y. Li, J. Luo, M. Sun, Z. Zhong and Y. Jing (2016). Effects of [N] management on garlic yield, economic benefit and soil apparent nutrient balance. J. Adv. Agric., 6: 883-887.

Brown, J.D. and O. Lilliland (1964). Rapid determination of potassium and sodium in plant material and soil extracts by flame photometer. Proc. Amer. Soc. Hort. Sci., 48: 341-346.

Chibu, H. and H. Shibayama (2003). In "Effects of Chitosan Application on the Growth of Several Crops". Chitin and Chitosan in Life Science. (Uragami, T.; K. Kurita and T. Fukamizo Eds.). Yamaguchi, Japan, p. 235-239.

Corradini, E., M.R. de Moura and L.H.C. Mattoso (2010). A preliminary study of the incorporation of NPK fertilizer into chitosan nanoparticles. eXPRESS Polymer Letters, 4 (8): 509-515.

Cottenie, A., M. Verloo, L. Kickens, G. Velghe and R. Camerlynck (1982). In "Chemical Analysis of Plants and Soils". Laboratory of Analytical and Agrochemistry. State University, Ghent Belgium, pp. 63.

Farooqui, M.A., I.S. Naruka, S.S. Rathore, P.P. Singh and R.P.S. Shaktawat (2009). Effect of $[\mathrm{N}]$ and sulphur levels on growth and yield of garlic (Allium sativum L.). As. J. Food Ag-Ind., Special Issue, S18-23.

Gaviola, S. and V.M. Lipinski (2008). Effect of [N] fertilization on yield and color of red garlic (Allium sativum) cultivars. Cien. Inv. Agr., 35 (1): 57-64.

Gornik, K., M. Grzesik and B.R. Duda (2008). The effect of chitosan on rooting of gravevine cuttings and on subsequent plant growth under drought and temperature stress. J. Fruit Ornam. Plant Res., 16: 333343.

Jiang, Y.M. and Y.B. Li (2001). Effects of chitosan coating on postharvest life and quality of longan fruit. Food Chem., 73: 139-143.

Kittur, F.S., K.R. Kumar and R.N. Tharanathan (2001). Functional packaging of chitosan films. Z. Tebensmittel Unterssuchung Undforshung, 206: 44-47.

Klute, A.J. (1986). In "Methods of Soil Analysis". No. 9, Part 1 - Physical and Mineralogical Methods. Am. Soc., Agron., Inc. Soil. Sci., Mad., Wisc., USA.

Liu, R. and R. Lal (2015). Potentials of engineered nanoparticles as fertilizers for increasing agronomic productions. A review. Science of the Total Environment, 514: 131-139.

Mondal, M.M.A., M.A. Malek, A.B. Puteh, M.R. Ismail, M. Ashrafuzzaman and L. Naher (2012). Effect of foliar application of chitosan on growth and yield in okra. Aust. J. Crops Sci., 6 (5): 918-921.

Naderi, M.R. and A. Danesh-Sharaki (2013). Nanofertilizers and their role in sustainable agriculture. International Journal of Agriculture and Crop Sciences, 5(19): 2229-2232.

Egyptian J. Desert Res., 68, No. 1, 135-155 (2018) 
Nori, M., F. Bayat and A. Esmaeili (2012). Changes of vegetative growth indices and yield of garlic (Allium sativum L.) in different sources and levels of [N] fertilizer. Int. J. Agri. Crop Sci., 4 (18): 1394-1400.

Page, A.L., Miller R.H. and D.R. Keeney (1982). In "Methods of soil analysis" No. (9), Part 2. Chemical and Microbiological Properties. Am. Soc., Agron., Inc. Soil. Sci., Mad., Wisc., USA.

Rana, G., N. Katerji, M. Mastrorilli, C.R. Camp, E.J. Sadler and R.E. Yoder (1996). Evapotranspiration measurement of crops under water stress: Evapotranspiration and irrigation scheduling. Proc. Inter. Conf., San Antonio, Texas, USA, pp. 691-696.

Said, A.S., F.F. Zakaria and H.R. El-Ramady (2012). Response of cucumber plants to foliar application of chitosan and yeast under greenhouse conditions. Aust. J. Basic and Appl. Sci., 6 (4): 63-71.

Saigusa, M. (2000). Broadcast application versus band application of polyolefin-coated fertilizer on green peppers grown on andisol. Journal of Plant Nutrition, 23: 1485-1493.

Sardi, K. and Timar E. (2005). Response of garlic (Allium sativum L.) to varying fertilization levels and nutrient ratios. Communication in Soil Science and Plant Analysis, 36: 673-679.

Teodorescu, M., A. Lungu, P.O. Stanescu and C. Neamtu (2009). Preparation and properties of novel slow-release NPK agrochemical formulations based on poly (acrylic acid) hydrogels and liquid fertilizer. Ind. Engin. Chem. Res., 48: 6527-6534.

Thomas, M.L. and F.G. Hills (1975). In "Statistical Methods in Agric. Research". Univ. of California, Davis 95616, $2^{\text {nd }}$ printing, pp. 6774.

Wojdyla, A.T. (2001). Chitosan in the control of rose disease: six years trials. Bull. Polish. Acad. Sci. Biol. Sci., 49: 233-252.

$\mathrm{Wu}, \mathrm{L}$. and M. Liu (2008). Preparation and properties of chitosan coated NPK compound fertilizer with controlled release and water-retention. Carbohydrate Polymers, 72: 240-247.

Egyptian J. Desert Res., 68, No. 1, 135-155 (2018) 


\section{تأثير الرش بالنتروجين المحمل على جزيئات الكيتوزان المتناهية في الصغر الصني على النمو والإنتاجية للثوم تحت ظروف الأراضي الرملية}

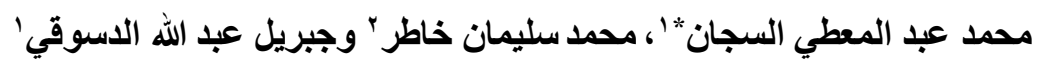

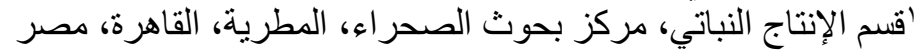

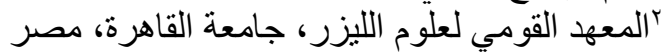

في دراسة أجريت في محطة بحوث بالوظة التابعة لمركز بحوث الصحر المراء باء بمحافظة شمال

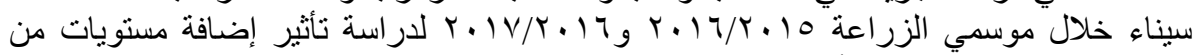

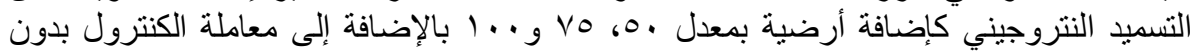

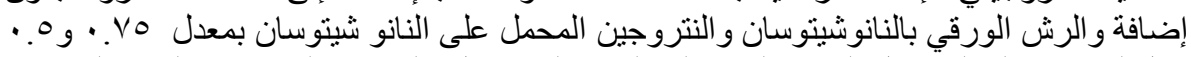

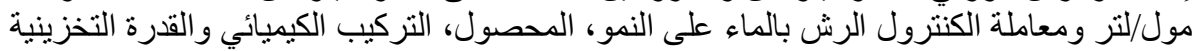

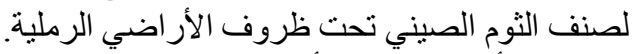

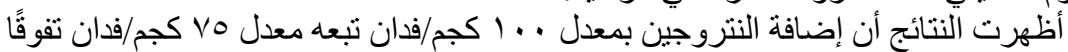

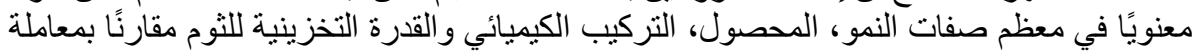

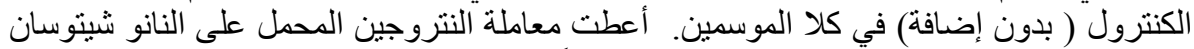

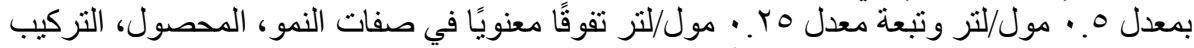

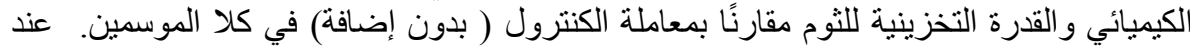

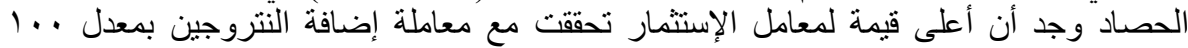

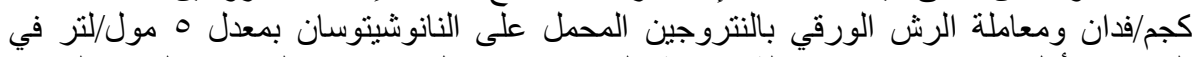

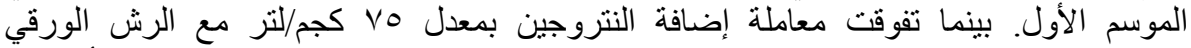

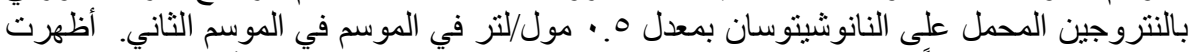

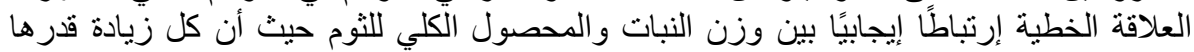

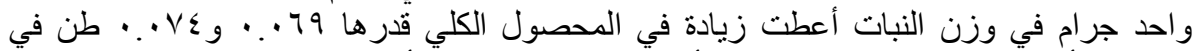

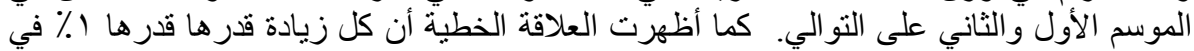

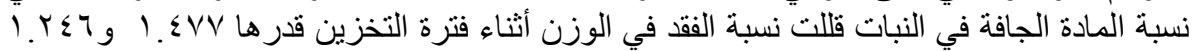
في الموسم الأول و الثناني، على التوالي.

Egyptian J. Desert Res., 68, No. 1, 135-155 (2018) 